\title{
EFFECT OF SOCIAL MEDIA MARKETING ACTIVITIES ON BRAND LOYALTY: THE MEDIATOR ROLE OF E-BRAND LOVE AND BRANDING CO-CREATION ${ }^{1}$
}

*Aysel ERCIS (Orcid ID: 0000-0002-9835-8574)

*Busra HOS (Orcid ID: 0000-0002-6557-9362)

*F. Gorgun DEVECI ${ }^{\S}$ (Orcid ID: 0000-0001-8987-2478)

*Atatürk University, Turkey

${ }^{\S}$ Corresponding Author

\begin{abstract}
In this study, it was aimed to determine the effect of social media marketing activities on brand loyalty. In this direction, it was targeted to determine whether the e-brand love and branding co-creation have a mediator role in the relationship between social media marketing activities, by which conducted clothing brands and brand loyalty. Another aim of the study is to reveal the effect of e-brand love and branding co-creation variables on brand loyalty. As a result of the research, it was determined that the entertainment, e-word of mouth and interaction have an impact on e-brand love and branding cocreation. Additionally, e-brand love and branding co-creation have effect on brand loyalty. At the same time, e-brand love and branding co-creation have a mediator role in the relationship between social media marketing activities and brand loyalty.
\end{abstract}

Keywords: Brand Loyalty, Branding Co-Creation, E-Brand Love, Social Media Marketing Activities INTRODUCTION

Social media marketing (SMM) is the use of social media to achieve the organizational objectives in terms of enterprises (Felix et al., 2017; 123). SMM has been studied by different researchers in different ways and dimensions (Kim and Ko, 2012; Seo and Park, 2018). In this study, SMM is discussed in five dimensions in line with the purpose of the research. These dimensions are entertainment, interaction, trendiness, customization and e-word of mouth. Brand love is to have strong emotions and attitudes towards a brand (Batra et al., 2012). In terms of social media platforms, loyalty, which is defined as "constantly following fan pages and suggesting them to other users" (Ruiz-Mafe et al., 2014; 365), is an important element in providing sustainable competitive advantages for brands (Gounaris and Stathakopoulos, 2004). Co-creation, which is one of the strongest success indicators of today's brands, is a customer-oriented teamwork and consists of the innovations and improvements performed based on the mutual communication between the customer and the enterprise (Ehlen et al., 2017; France et al., 2015; Piller et al., 2012). When the literature was examined, it was seen that the concepts such as loyalty and trust were also evaluated through online platforms and there were studies in which the concepts such as eloyalty and e-trust were defined (Gommans et al., 2001; Merrilees and Fry, 2003). At this point, although there are studies conducted on brand love through social media, there are limited studies directly addressing the concept of "e-brand love." In addition, the research is one of the few studies examining the effect of SMM activities on branding co-creation. Detailed information regarding the research variables is presented below.

\footnotetext{
${ }^{1}$ This research derived from "Effect of Social Media Marketing Activities on Brand Loyalty: The Mediator Role of E-Brand Love and Branding Co-Creation" and presented full text at the "(ICLTIBM 2019) 9th International Conference on Leadership, Technology, Innovation and Business Management: Leadership, Innovation, Media and Communication”, 12-13 December 2019, İstanbul, Turkey.
} 


\section{LITERATURE REVIEW AND THEORETICAL FRAMEWORK Social Media Marketing Activities}

Social media marketing, which has been one of the effective marketing methods in recent years, is to conduct various marketing activities related to the current products and services of companies through social media platforms (Yadav and Rahman 2017; 1296). Through SMM, brands can find the opportunity to introduce their brand to their current or potential customers via social media tools such as Facebook, Twitter and YouTube (Saravanakumar and SuganthaLakshmi, 2012). In the studies conducted on SMM, it was observed that different dimensions were created and these dimensions were applied in different sectors (Kim and Ko, 2012; Seo and Park, 2018; Yadav and Rahman, 2017). The study of Kim and Ko (2012)'s dimensions were utilized in this study and as SMM dimensions, entertainment, interaction, trendiness and customization were used. The variable of e-word of mouth was added to these dimensions. The dimensions of SMM are explained as follows: Entertainment is the result of the pleasure and satisfaction obtained through social media (Agichtein et al., 2008). Contents thought to be enjoyable have a higher level of participation and contribution (Cvijikj and Michahelles, 2013; Muntinga et al., 2011). Interaction is to share information and exchange ideas with others through social media (Godey et al., 2016; 5835). It was determined that consumers who had high interaction with the brand were more willing to provide feedback (Chung and Austria, 2010). Trendiness is to provide customers with the latest and up-to-date information regarding products (Godey et al., 2016; 5835). This variable is accepted as one of the important SMM activities that positively affect brand awareness and brand image (Seo and Park, 2018). Customization is the degree at which social media channels provide customized information search and service for customers (Godey et al., 2016; 5835). It was detected that a customized service experienced by consumers positively affected the intention of repurchase and word of mouth communication (Cifci and Sözen, 2017). E-word of mouth refers to the positive or negative feedback provided by the customers about the available products in an internet-mediated environment (HennigThurau et al., 2004; 39). E-word of mouth has a positive effect on purchase intent and brand loyalty (Balakrishnan et al., 2014). In the researches conducted on this subject, it was seen that SMM activities had a positive effect on brand loyalty, brand awareness and brand image (Algharabat, 2017; Godey et al., 2016; Ismail, 2017). Accordingly, the following hypotheses were developed regarding SMM activities.

H1: SMM activities are effective on e-brand love.

H2: SMM activities are effective on branding co-creation.

\section{E-Brand Love}

Brand love is generally described as "the passionate emotional commitment of the customer to a particular trading name" (Carroll and Ahuvia, 2006; 81). E-brand love, on the other hand, can be defined as "the strong bond established through social media by the development or formation of emotions that lead to a passionate intimacy between the consumer and the brand." In the studies conducted within the scope of social media, it was determined that the consumers, who loved their brands, were willing to publish the shares of the related brands through their social media accounts (Baena, 2016). It was also suggested that the positive consumer reactions given to the "love" icon on Instagram and "like" icon on Facebook were a reflection of brand love (Vernuccio et al., 2015; Wallace et al., 2014). In the study conducted by Machado et al., (2019), it was determined that consumer-brand engagement via Facebook had a significant effect on the formation of brand love. Kaufmann et al. (2016), on the other hand, put forward that consumers who were committed to the brand with love were more willing to join branding co-creation. In the light of the information presented above, the following hypotheses were developed.

H3: E-brand love is effective on brand loyalty.

H4: E-Brand love has a mediator role in the relationship between SMM activities and brand loyalty.

\section{Branding Co-Creation}

Co-creation, which is an important variable in terms of branding, is defined as "the intention of customers to exchange information with other customers for the purpose of increase the value of the brand." In this process, social media is used as an effective tool in terms of facilitating communication and enhancing consumer-brand relations as well as involving the consumer in the process of branding and co-creation 
(Hajli et al., 2017; Piller et al., 2012). In the studies conducted, it was determined that the consumers involved in the co-creation process perceived the brand value at a higher level; and they had higher levels in terms of providing brand-related information to other consumers, giving feedback to the brand and purchase intention (France et al., 2015; Hsieh and Chang, 2016). In addition, each consumer involved in the co-creation process was seen as an alternative source of new ideas for the brand (Hoyer et al., 2010). In a few studies conducted within the scope of branding, it was observed that the quality of the relationship on social commerce sites positively affected the co-creation intention of consumers (Wang and Hajli, 2014). Likewise, consumers' trust in their brands encourages them to engage in the process of branding co-creation (Kamboj et al., 2018). In the light of the information presented above, the following hypotheses were developed.

H5: Branding co-creation is an effective on brand loyalty.

H6: Branding co-creation has a mediator role in the relationship between SMM activities and brand loyalty.

\section{Brand Loyalty}

According to Oliver (1999; 34) brand loyalty "exhibiting a behavior of repurchasing a previously purchased brand in the future, too." It was revealed that activities such as conducting advantageous campaigns through social media, presenting brand-related contents and producing popular contents had a positive effect on brand loyalty (Erdoğmuş and Çiçek, 2012). Furthermore, establishing closer brandcustomer and customer-customer relationships in social media brand communities was seen as a path going to brand loyalty (Laroche et al., 2013). In a study conducted by Gamboa and Gonçalves (2014), it was stated that following brand fan pages by consumers via Facebook had an effect on the development of trust, satisfaction, perceived value and commitment, and this situation resulted in brand loyalty. Kim et al., (2014) determined that "retweeting" the shares of the brand via Twitter affected brand loyalty.

\section{RESEARCH METHOD}

\section{Purpose, Scope and Limitations of the Study}

In this study, it was aimed to determine the mediator role of e-brand love and branding co-creation in the effect of SMM activities on brand loyalty. The main population of the research consisted of the consumers living in Samsun, aged 18 and over, having various social media accounts and following the brand they "love" through these social media tools. The study only focused on clothing brands. Therefore, the results obtained from the research cannot be generalized for other product groups and Turkey.

\section{Research Model}

The model developed in line with the purpose of the research is shown in Figure 1.

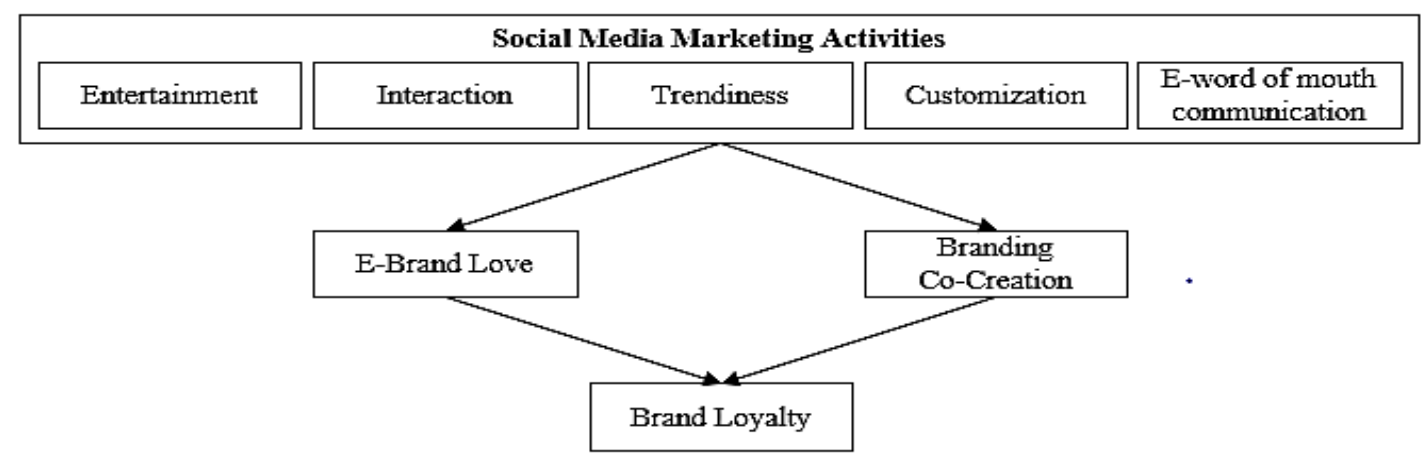

Figure 1. Research Model

\section{Sampling Process}

The main population of the research consisted of the consumers living in Samsun, aged 18 and over, having various social media accounts and following the brand they "love" through these social media 
tools. Convenience sampling method was used as the sampling method. A questionnaire was conducted on 425 individuals and 417 of them were assessed after the incomplete forms were eliminated.

\section{Data Collection Method and Tool}

The questionnaire form was applied only to the participants who were following the brand via social media accounts and consisted of three different question groups. The preliminary questions included in the first group were adapted from the questions obtained from the study conducted by Tekbiyık (2017). The respondents were then asked to specify their favourite clothing brands and to answer the next questions by considering this brand. The last question of the first group was to determine on which social media account/accounts the brand was followed. The questions in the second group were asked to determine the evaluations of consumers regarding the study variables. In this group, the four dimensions of SMM activities were obtained from the scale developed by Kim and Ko (2012). In the questions of eword of mouth, the fifth dimension, the study conducted by Karjaluoto et al. (2016) was utilized. The questions regarding brand love were obtained from the study of Carroll and Ahuvia (2006), questions regarding branding co-creation were obtained from the study of Wang and Hajli (2014) and questions regarding brand loyalty were obtained from the study of Godey et al. (2016). In the last part of the questionnaire, the questions regarding demographic characteristics were included. Prior to the final questionnaire, a preliminary study was applied to a sample consisting of 20 individuals and the questionnaire was finalized. The questions regarding the research variables were measured with the 5point Likert scale $(1=$ Strongly disagree, $5=$ Strongly agree). The data were analyzed with AMOS and SPSS 20.0 statistical programs. Descriptive statistics, exploratory factor analysis, confirmatory factor analysis and structural equation modelling were used in the analysis of the data.

\section{FINDINGS}

\section{Demographic Characteristics and Other Descriptive Statistics}

Most of the respondents consisted of single people (60.0\%), students (42.9\%) and females $(68.3 \%)$ who were in the 18-25 (51.6\%) age range, received education at undergraduate level (70.5\%), had an income level of $1000 \mathrm{TL}$ and below (38.1\%). The respondents were first asked which social media accounts they were following. According to the results, Instagram (91.1\%), Facebook (73.9\%), Twitter $(50.6 \%)$ and Snapchat $(40.0 \%)$ were found to be the most commonly used social media accounts. Secondly, the respondents' frequency of using social media accounts and whether they used social media actively were asked. The majority of the respondents use social media continuously $(57.3 \%)$ and a few times in a day (34.1\%). In addition, it was determined that the statement "I post on social media" came to the forefront with an average of $65.0 \%$ and the statement "I just follow what is written on social media" followed it with an average of $58.0 \%$. The respondents were asked to specify their favourite brands as an open-ended question in the questionnaire form. As a result of the questionnaires evaluated, it was observed that the respondents specified 45 different clothing brands. The top 5 brands having the highest percentage distribution are Zara (14.9\%), Koton (11.3\%), H\&M (8.4\%), Mavi (6.7\%) and Adidas (6.5\%).

\section{Exploratory Factor Analysis}

Before carrying out confirmatory factor analysis, exploratory factor analysis was performed to clearly determine the dimensions of the scales used in the research. Factor loads of 0.30 and above were taken into account in the exploratory factor analysis. Firstly, exploratory factor analysis was performed on SMM activities and the variables were grouped under 3 factors. The obtained factors explained $61.643 \%$ of the total variance (KMO Measure of Sampling Adequacy: 83\%; Barlett Sphericity Test: 1371.899; df: 55). During the analysis, 1 statement was excluded from the analysis. The results of the exploratory factor analysis are presented in Table 1. 
Journal of Global Strategic Management | V. 14 | N. 1 | 2020-June | isma.info | 069-084 | DOI: 10.20460/JGSM.2020.287

Table 1. Results of Exploratory Factor Analysis of SMM Activities

\begin{tabular}{|l|c|c|c|}
\hline \multicolumn{1}{|c|}{ Variables } & Factor Loading & \% of Variance & Eigenvalues \\
\hline $\begin{array}{l}\text { Factor 1: Entertainment and Trendiness } \\
(\boldsymbol{\alpha}=\mathbf{0 . 7 4 2})\end{array}$ & & $\mathbf{2 3 . 9 2 5}$ & $\mathbf{2 . 6 3 2}$ \\
\hline $\begin{array}{l}\text { This brand's social media contents seem } \\
\text { interesting. }\end{array}$ & 0.713 & & \\
\hline Following this brand's social media is fun. & 0.684 & & \\
\hline $\begin{array}{l}\text { This brand's social media contents are the newest } \\
\text { information. }\end{array}$ & 0.658 & & \\
\hline $\begin{array}{l}\text { This brand's social media enables information } \\
\text { sharing. }\end{array}$ & 0.646 & & \\
\hline $\begin{array}{l}\text { This brand's social media offers customized } \\
\text { information search. }\end{array}$ & 0.624 & & \\
\hline Following this brand's social media is very trendy. & 0.518 & & \\
\hline Factor 2: E-Word of Mouth ( $\boldsymbol{\alpha}=\mathbf{0 . 8 5 9 )}$ & & $\mathbf{2 3 . 0 0 7}$ & \\
\hline $\begin{array}{l}\text { I write positive word of mouth about this brand on } \\
\text { the social media platforms. }\end{array}$ & 0.869 & & \\
\hline I "talk up" this brand in social media platforms. & 0.839 & & $\mathbf{1 . 6 1 8}$ \\
\hline $\begin{array}{l}\text { I try to spread the positive sharing about this brand } \\
\text { in social media platforms. }\end{array}$ & 0.812 & & \\
\hline Factor 3: Interaction ( $\boldsymbol{\alpha}=\mathbf{0 . 6 8 0 )}$ & & $\mathbf{1 4 . 7 1 1}$ & \\
\hline $\begin{array}{l}\text { This brand's social media is possible to exchange } \\
\text { conversation or opinion with others. }\end{array}$ & 0.790 & & \\
\hline $\begin{array}{l}\text { It is easy to deliver my opinion through this brand's } \\
\text { social media. }\end{array}$ & 0.754 & & \\
\hline
\end{tabular}

In addition, the results of the exploratory factor analysis related to the other scales used in the research are as follows; E-brand love, branding co-creation and brand loyalty scales were included in the research model as one-dimensional scales which did not had sub-dimensions. As a result of the exploratory factor analysis, it was seen that they were gathered under one dimension. Two reverse-coded statements were excluded from the exploratory factor analysis related to the brand love scale. The single-factor structure explained $51.505 \%$ of the total variance (KMO Measure of Sampling Adequacy: 87.7\%; Barlett Sphericity Test: 1197.854; df: 28). None of the statements belonging to the scale of branding co-creation were eliminated and the single-factor structure explained $64.474 \%$ of the total variance (KMO Measure of Sampling Adequacy: 67.5\%; Barlett Sphericity Test: 220.881; df: 3). In the brand loyalty scale, the single-factor structure explained $60.765 \%$ of the total variance (KMO Measure of Sampling Adequacy: 78.4\%; Barlett Sphericity Test: 744.460; df: 10 ). The variables and explanations after the analysis are shown in Table 2. 
Journal of Global Strategic Management | V. 14 | N. 1 | 2020-June| isma.info | 069-084 | DOI: 10.20460/JGSM.2020.287

Table 2. Results of E-Brand Love, Branding Co-Creation and Brand Loyalty Exploratory Factor Analysis

\begin{tabular}{|c|c|c|c|}
\hline Variables & Factor Loading & $\%$ of Variance & Eigenvalues \\
\hline E-Brand Love $(\alpha=0.865)$ & & 51.505 & 4.120 \\
\hline I am passionate about this brand. & 0.789 & & \\
\hline This is a wonderful brand. & 0.768 & & \\
\hline Everything about this brand is a pure delight. & 0.753 & & \\
\hline I'm very attached to this brand. & 0.733 & & \\
\hline This brand is totally awesome. & 0.718 & & \\
\hline This brand makes me very happy. & 0.701 & & \\
\hline This brand makes me feel good. & 0.661 & & \\
\hline I love this brand. & 0.598 & & \\
\hline Branding Co-Creation $(\alpha=0.724)$ & & 64.474 & 1.934 \\
\hline $\begin{array}{l}\text { I am willing to buy the products of a brand recommended by my } \\
\text { friends on my favourite social media platforms. }\end{array}$ & 0.827 & & \\
\hline $\begin{array}{l}\text { I will consider the shopping experiences of my friends on my } \\
\text { favourite social media platform when I want to shop a brand. }\end{array}$ & 0.809 & & \\
\hline $\begin{array}{l}\text { I am willing to provide my experiences and suggestions when } \\
\text { my friends on my favourite social media platform want my } \\
\text { advice on buying something from a brand. }\end{array}$ & 0.772 & & \\
\hline Brand Loyalty $(\alpha=0.795)$ & & 60.765 & 3.038 \\
\hline I intend to visit this brand's social media account again. & 0.818 & & \\
\hline I regularly visit this brand's social media account. & 0.805 & & \\
\hline I would love to recommend this brand to my friends. & 0.801 & & \\
\hline I will suggest this brand to other consumers. & 0.794 & & \\
\hline This brand would be my first choice. & 0.670 & & \\
\hline
\end{tabular}

\section{Confirmatory Factor Analysis}

Confirmatory factor analysis was used to test whether SMM activities, e-brand love, branding co-creation and brand loyalty scales were suitable for sampling. The results of the confirmatory factor analysis are given below.

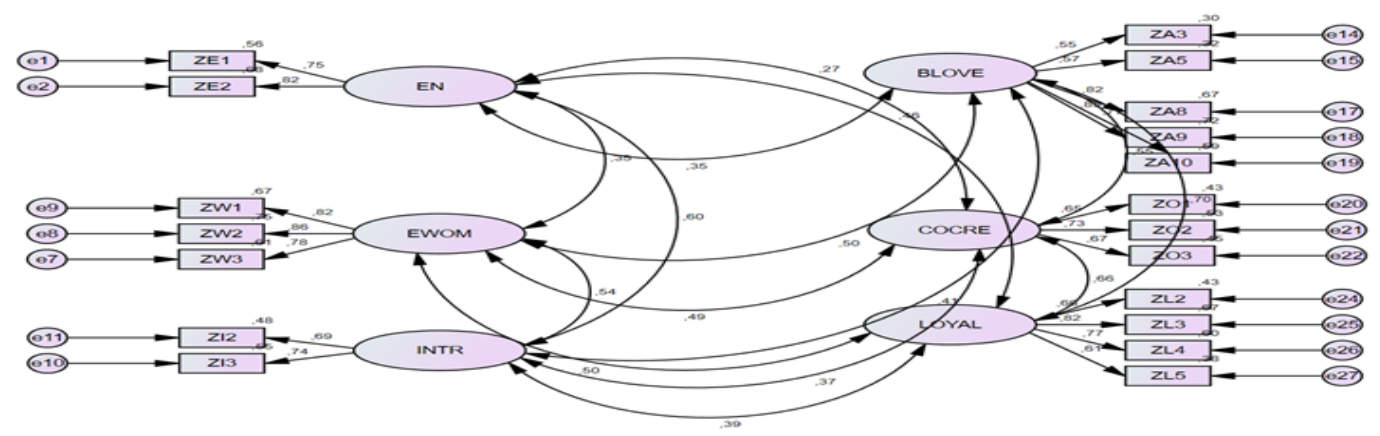

Figure 2. Results of Confirmatory Factor Analysis

According to the results of the confirmatory factor analysis performed to determine whether the scales used in the research were in compliance with the sample, fit indexes are as follows: $\mathrm{CMIN} / \mathrm{df}=1.942$; $\mathrm{RMSEA}=0.051 ; \mathrm{RMR}=0.038 ; \mathrm{AGFI}=0.903 ; \mathrm{GFI}=0.930 ; \mathrm{NFI}=0.912 ; \mathrm{CFI}=0.955$. The variables that 
Journal of Global Strategic Management | V. 14 | N. 1 | 2020-June | isma.info | 069-084 | DOI: 10.20460/JGSM.2020.287

exceeded the standard coefficients (very close to 1.0) or giving very large standard errors were checked and non-conforming variables were excluded following the analysis performed (Hair et al., 1998). Accordingly, 4 statements regarding entertainment and trendiness dimensions were excluded from the analysis. The dimension was named as "entertainment" since only the statements of entertainment remained in the dimension. In addition, 3 statements regarding brand love and 1 statement regarding brand loyalty were eliminated. After the confirmatory factor analysis, the reliability, AVE and CR values of the scales are as follows.

Table 3. Cronbach's Alpha, CR and AVE Values of The Scales

\begin{tabular}{|l|c|c|c|}
\hline \multicolumn{1}{|c|}{ Variables } & Cronbach's Alpha & CR & AVE \\
\hline Entertainment & 0.763 & 0.766 & 0.621 \\
\hline E-Word of Mouth & 0.857 & 0.861 & 0.674 \\
\hline Interaction & 0.680 & 0.681 & 0.516 \\
\hline E-Brand Love & 0.836 & 0.840 & 0.520 \\
\hline Branding Co-Creation & 0.724 & 0.726 & 0.469 \\
\hline Brand Loyalty & 0.731 & 0.809 & 0.518 \\
\hline
\end{tabular}

According to the results in the table, CR values are generally above 0.70 and AVE values are above 0.50 . The values obtained regarding the variables after the confirmatory factor analysis are as follows.

Table 4. Values Related to The Scales Used in The Study

\begin{tabular}{|c|c|c|c|c|c|}
\hline & Standardized Regression Weights & S.E. & C.R. & $\mathbf{p}$ & $\mathbf{R}^{2}$ \\
\hline $\mathrm{ZW} 3 \leftarrow \mathrm{EWOM}$ & 0.781 & & & & 0.610 \\
\hline $\mathrm{ZW} 2 \leftarrow \mathrm{EWOM}$ & 0.863 & 0.066 & 16.404 & $* * *$ & 0.745 \\
\hline $\mathrm{ZW} 1 \leftarrow \mathrm{EWOM}$ & 0.817 & 0.064 & 15.786 & $* * *$ & 0.668 \\
\hline $\mathrm{ZI} 3 \leftarrow \mathrm{INTR}$ & 0.744 & & & & 0.553 \\
\hline $\mathrm{ZI} 2 \leftarrow \mathrm{INTR}$ & 0.692 & 0.101 & 9.073 & $* * *$ & 0.479 \\
\hline $\mathrm{ZA} 3 \leftarrow \mathrm{BLOVE}$ & 0.547 & & & & 0.299 \\
\hline $\mathrm{ZA} 5 \leftarrow \mathrm{BLOVE}$ & 0.569 & 0.119 & 8.476 & $* * *$ & 0.324 \\
\hline $\mathrm{ZA} 8 \leftarrow \mathrm{BLOVE}$ & 0.818 & 0.150 & 10.501 & $* * *$ & 0.669 \\
\hline ZA9 & 0.850 & 0.155 & 10.676 & $* * *$ & 0.722 \\
\hline ZA10־BLOVE & 0.766 & 0.146 & 10.163 & $* * *$ & 0.587 \\
\hline $\mathrm{ZO} 1 \leftarrow \mathrm{COCRE}$ & 0.652 & & & & 0.426 \\
\hline $\mathrm{ZO} 2 \leftarrow \mathrm{COCRE}$ & 0.729 & 0.113 & 10.048 & $* * *$ & 0.532 \\
\hline $\mathrm{ZO} 3 \leftarrow \mathrm{COCRE}$ & 0.672 & 0.107 & 9.656 & $* * *$ & 0.452 \\
\hline ZL2 $\leftarrow$ LOYAL & 0.655 & & & & 0.429 \\
\hline ZL3 & 0.817 & 0.105 & 12.521 & $* * *$ & 0.667 \\
\hline $\mathrm{ZL} 4 \leftarrow \mathrm{LOYAL}$ & 0.774 & 0.032 & 12.095 & $* * *$ & 0.599 \\
\hline ZL5 LOYAL & 0.613 & 0.100 & 10.048 & $* * *$ & 0.376 \\
\hline $\mathrm{ZE} 2 \leftarrow \mathrm{EN}$ & 0.825 & 0.114 & 9.798 & $* * *$ & 0.680 \\
\hline $\mathrm{ZE} 1 \leftarrow \mathrm{EN}$ & 0.749 & & & & 0.561 \\
\hline
\end{tabular}


Journal of Global Strategic Management | V. 14 | N. 1 | 2020-June | isma.info | 069-084 | DOI: 10.20460/JGSM.2020.287

\section{Testing the Research Model}

Structural equation modelling was used to test the research model. The results of the model which aimed to determine the effect of social media marketing activities on brand loyalty are as follows.

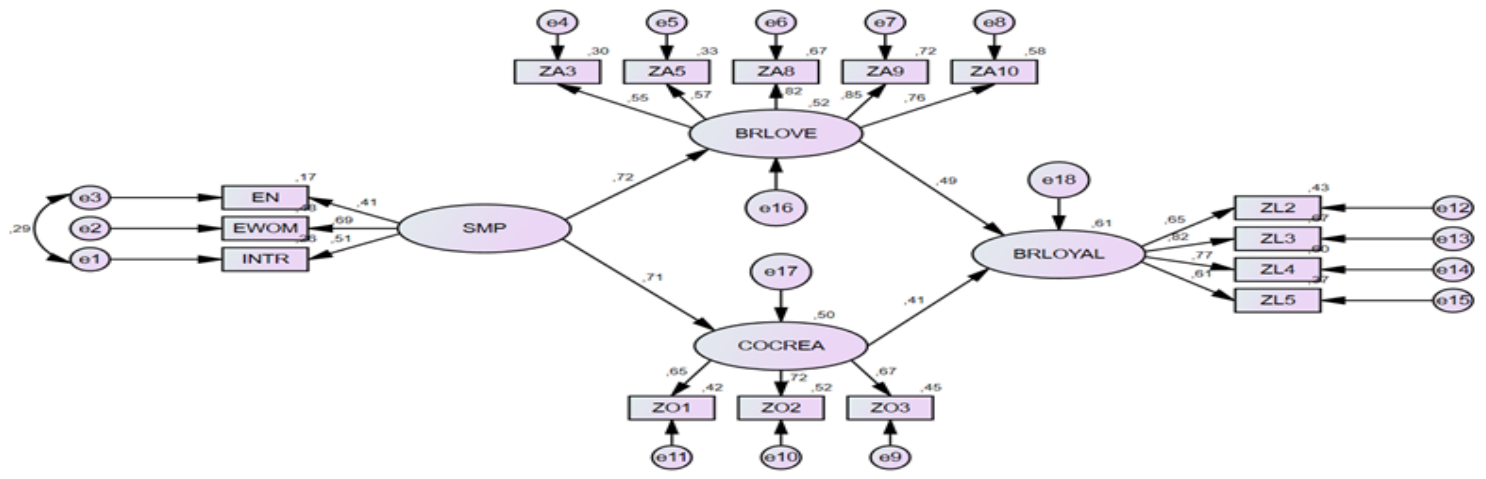

Figure 3. Model Test Results

The fit indices regarding the research model are as follows: $\mathrm{CMIN} / \mathrm{df}=2.307$; $\mathrm{RMSEA}=0,06$; $\mathrm{RMR}=$ 0.043; $\mathrm{AGFI}=0.904 ; \mathrm{GFI}=0.932 ; \mathrm{NFI}=0.909 ; \mathrm{CFI}=0.946)$. The results of the structural equation analysis regarding the variables are presented in Table 5 below.

Table 5. Research Model Values

\begin{tabular}{|c|c|c|c|c|}
\hline & Standardized Regression Weights & S.E. & C.R. & $\mathbf{p}$ \\
\hline BRLOVE $\leftarrow$ SMP & 0.721 & 0.132 & 6.358 & $* * *$ \\
\hline $\mathrm{COCREA} \leftarrow \mathrm{SMP}$ & 0.706 & 0.156 & 6.575 & $* * *$ \\
\hline BRLOYAL $\leftarrow$ BRLOVE & 0.485 & 0.085 & 6.287 & $* * *$ \\
\hline BRLOYAL $\leftarrow$ COCREA & 0.413 & 0.065 & 5.627 & $* * *$ \\
\hline INTR $\leftarrow$ SMP & 0.511 & & & \\
\hline $\mathrm{EWOM} \leftarrow \mathrm{SMP}$ & 0.692 & 0.267 & 7.564 & $* * *$ \\
\hline $\mathrm{EN} \leftarrow \mathrm{SMP}$ & 0.407 & 0.110 & 6.744 & $* * *$ \\
\hline $\mathrm{ZA} 3 \leftarrow \mathrm{BRLOVE}$ & 0.550 & & & \\
\hline $\mathrm{ZA} 5 \leftarrow \mathrm{BRLOVE}$ & 0.571 & 0.118 & 8.521 & $* * *$ \\
\hline $\mathrm{ZA} 8 \leftarrow \mathrm{BRLOVE}$ & 0.819 & 0.148 & 10.573 & $* * *$ \\
\hline $\mathrm{ZA} 9 \leftarrow \mathrm{BRLOVE}$ & 0.846 & 0.153 & 10.727 & $* * *$ \\
\hline $\mathrm{ZA} 10 \leftarrow \mathrm{BRLOVE}$ & 0.764 & 0.144 & 10.203 & $* * *$ \\
\hline $\mathrm{ZO} 3 \leftarrow \mathrm{COCREA}$ & 0.673 & & & \\
\hline $\mathrm{ZO} 2 \leftarrow \mathrm{COCREA}$ & 0.724 & 0.106 & 10.240 & $* * *$ \\
\hline $\mathrm{ZO} 1 \leftarrow \mathrm{COCREA}$ & 0.646 & 0.100 & 9.604 & $* * *$ \\
\hline ZL2 & 0.654 & & & \\
\hline ZL3־BRLOYAL & 0.817 & 0.106 & 12.409 & $* * *$ \\
\hline ZL4־BRLOYAL & 0.773 & 0.033 & 11.987 & $* * *$ \\
\hline ZL5־BRLOYAL & 0.611 & 0.101 & 9.964 & $* * *$ \\
\hline
\end{tabular}

According to the findings obtained: It is possible to state that as the positive evaluations of the consumer towards SMM activities increase, e-brand love also increases. SMM activities make consumers more 
willing to engage in the process of branding co-creation. Consumers having e-brand love show commitment to their brands. The increase in the loyalties of consumers shows parallelism with the increase in the intentions of the consumers who want to be involved in the process of branding cocreation. In the light of the results obtained the hypotheses H1, H2, H3 and H5 were accepted.

\section{Investigation of Mediator Effects}

Firstly, the direct relationship between SMM activities and brand loyalty was examined before analysing the mediator roles of e-brand love and co-creation variables in the relationship between SMM activities and brand loyalty. The results are presented below.

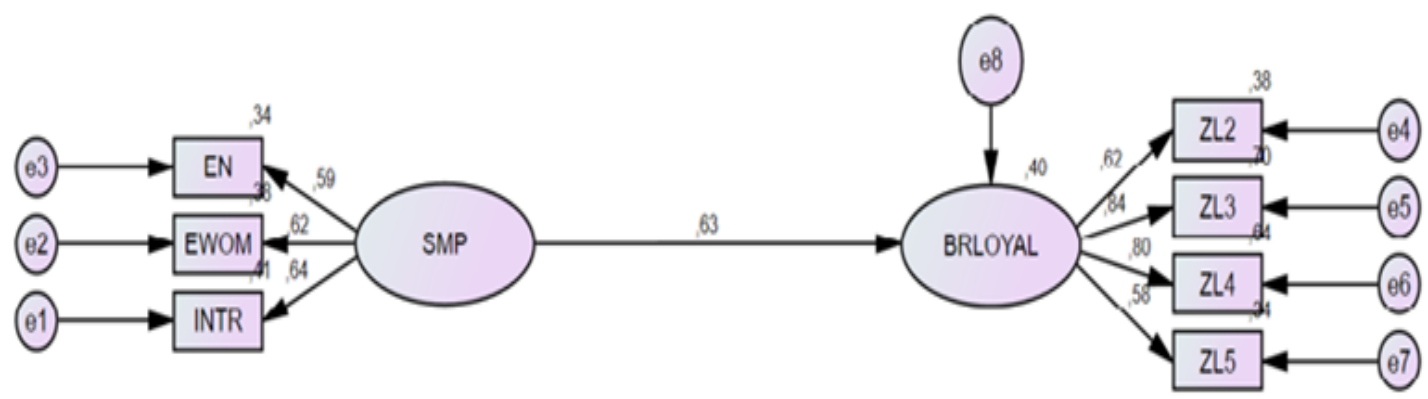

Figure 4. Direct Effect Model Between SMM Activities and Brand Loyalty

There is a statistically significant and positive relationship between SMM activities and brand loyalty. It is expected that this relationship will weaken or will be statistically insignificant if e-brand love and branding co-creation, which are the mediator variables, are added to the model $(\mathrm{CMIN} / \mathrm{df}=2.867$; $\mathrm{GFI}=$ 0.973; $\mathrm{AGFI}=0.942 ; \mathrm{RMR}=0.041$; RMSEA $=0.072$; $\mathrm{CFI}=0.966$; NFI $=0.950$; Standardized Regression Weights $=0.635 ;$ S.E. $=0.091 ;$ C.R. $\left.=6.707 ; \mathrm{P}=0.000 ; \mathrm{R}^{2}=0.403\right)$. The results are presented below.

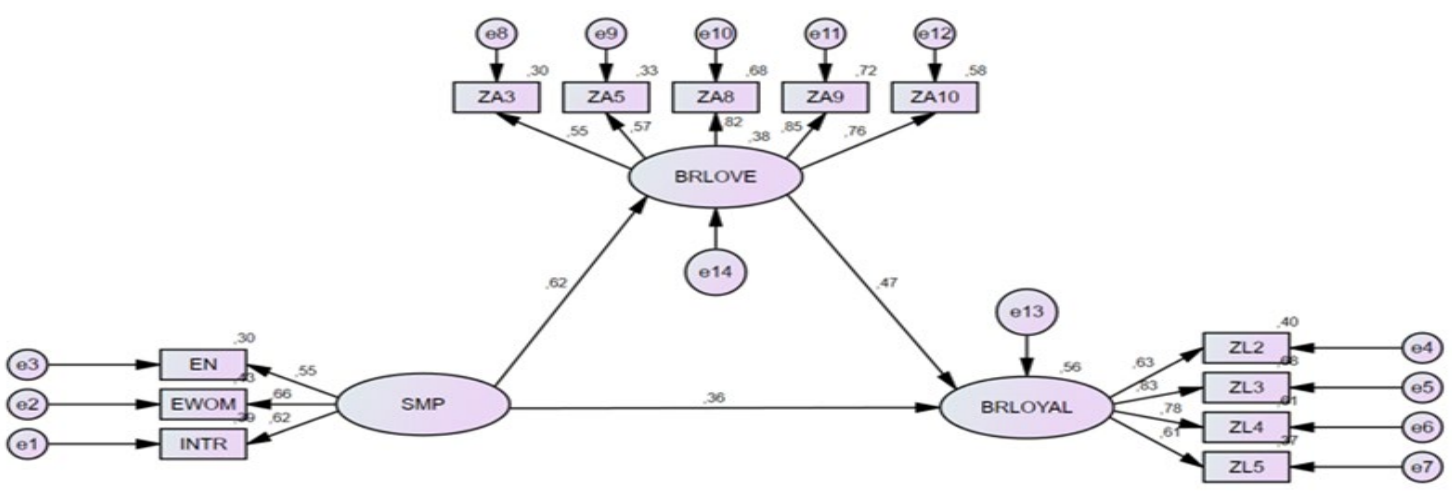

Figure 5. Mediator Role of E-Brand Love

As seen in the Figure 5, when the e-brand love variable is added to the relationship between SMM activities and brand loyalty with the mediator role, the relationship between SMM activities and brand loyalty weakens. Therefore, the partial mediator role of e-brand love can be mentioned $(\mathrm{CMIN} / \mathrm{df}=2.814$; $\mathrm{GFI}=0.939 ; \mathrm{AGFI}=0.906 ; \mathrm{RMR}=0.046$; $\mathrm{RMSEA}=0.071 ; \mathrm{CFI}=0.944 ; \mathrm{NFI}=0.917$ ). The results related to the model where the e-brand love variable is added with the mediator role are presented below. 
Journal of Global Strategic Management | V. 14 | N. 1 | 2020-June| isma.info | 069-084 | DOI: 10.20460/JGSM.2020.287

Table 6. Mediator Role of the E-Brand Love Variable Values

\begin{tabular}{|c|c|c|c|c|}
\hline & Standardized Regression Weights & S.E. & C.R. & $\mathbf{p}$ \\
\hline BRLOVE $\leftarrow$ SMP & 0.616 & 0.091 & 6.383 & $* * *$ \\
\hline BRLOYAL $\leftarrow B R L O V E$ & 0.471 & 0.095 & 5.331 & $* * *$ \\
\hline BRLOYAL $\leftarrow$ SMP & 0.360 & 0.092 & 3.983 & $* * *$ \\
\hline INTR $\leftarrow$ SMP & 0.623 & & & \\
\hline EWOM SMP & 0.657 & 0.190 & 8.270 & $* * *$ \\
\hline $\mathrm{EN} \leftarrow \mathrm{SMP}$ & 0.550 & 0.109 & 7.533 & $* * *$ \\
\hline $\mathrm{ZA} 3 \leftarrow \mathrm{BRLOVE}$ & 0.546 & & & \\
\hline $\mathrm{ZA} 5 \leftarrow \mathrm{BRLOVE}$ & 0.570 & 0.119 & 8.475 & $* * *$ \\
\hline $\mathrm{ZA} 8 \leftarrow \mathrm{BRLOVE}$ & 0.823 & 0.151 & 10.516 & $* * *$ \\
\hline ZA9 $-\mathrm{BRLOVE}$ & 0.849 & 0.156 & 10.653 & $* * *$ \\
\hline $\mathrm{ZA} 10 \leftarrow \mathrm{BRLOVE}$ & 0.760 & 0.146 & 10.108 & $* * *$ \\
\hline ZL2 $\leftarrow$ BRLOYAL & 0.634 & & & \\
\hline ZL3 & 0.826 & 0.114 & 12.030 & $* * *$ \\
\hline $\mathrm{ZL} 4 \leftarrow \mathrm{BRLOYAL}$ & 0.782 & 0.035 & 11.684 & $* * *$ \\
\hline ZL5๘BRLOYAL & 0.612 & 0.107 & 9.750 & $* * *$ \\
\hline
\end{tabular}

According to the Sobel Test results; test statistics was calculated as 4.091 while $\mathrm{p}$ value was calculated as 0.000 (http: //quantpsy.org/sobel).

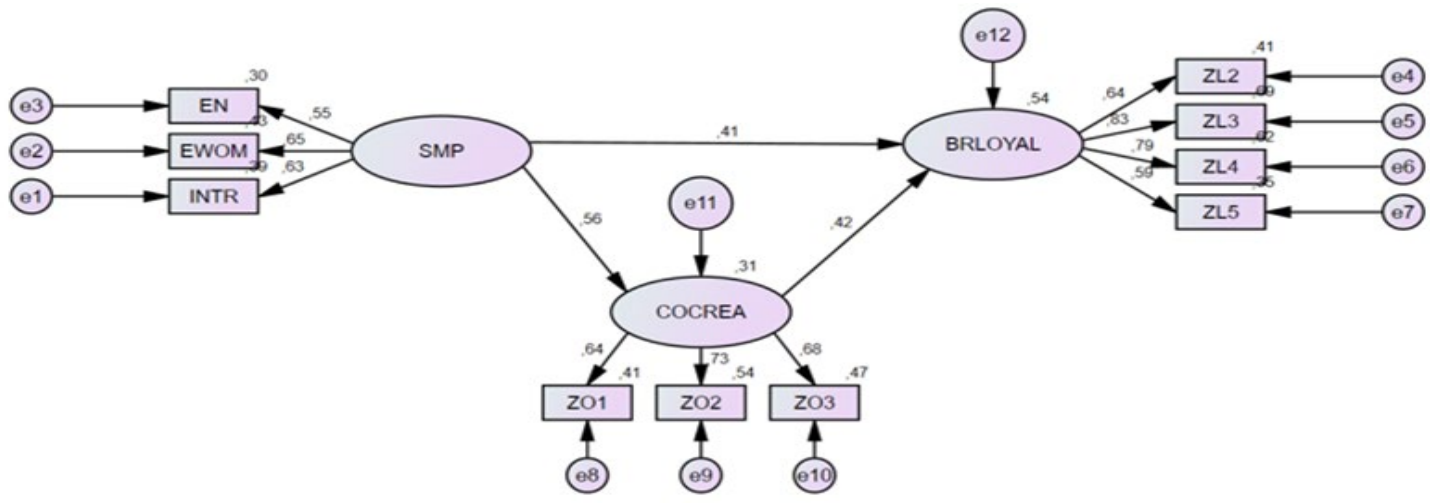

Figure 6. Mediator Role of Branding Co-Creation

Similarly, when the branding co-creation variable is added to the relationship between SMM activities and brand loyalty with the mediator role, the relationship between SMM activities and brand loyalty weakens $(\mathrm{CMIN} / \mathrm{df}=2.459 ; \mathrm{GFI}=0.959 ; \mathrm{AGFI}=0.929 ; \mathrm{RMR}=0.041 ; \mathrm{RMSEA}=0.063 ; \mathrm{CFI}=0.957 ; \mathrm{NFI}=$ 0.930). The results related to the model where the branding co-creation variable is added with the mediator role are shared below. 
Table 7. Mediator Role of Branding Co-Creation Values

\begin{tabular}{|c|c|c|c|c|}
\hline & Standardized Regression Weights & S.E. & C.R. & $\mathbf{p}$ \\
\hline COCREA $\leftarrow$ SMP & 0.557 & 0.110 & 6.069 & $* * *$ \\
\hline BRLOYAL $\leftarrow$ COCREA & 0.419 & 0.074 & 4.878 & $* * *$ \\
\hline BRLOYAL $\leftarrow$ SMP & 0.413 & 0.094 & 4.495 & $* * *$ \\
\hline $\mathrm{INTR} \leftarrow \mathrm{SMP}$ & 0.626 & & & \\
\hline EWOM $\leftarrow$ SMP & 0.655 & 0.193 & 8.092 & $* * *$ \\
\hline $\mathrm{EN} \leftarrow \mathrm{SMP}$ & 0.551 & 0.110 & 7.441 & $* * *$ \\
\hline $\mathrm{ZO} 3 \leftarrow$ COCREA & 0.683 & & & \\
\hline $\mathrm{ZO} 2 \leftarrow \mathrm{COCREA}$ & 0.733 & 0.106 & 10.177 & $* * *$ \\
\hline $\mathrm{ZO} 1 \leftarrow \mathrm{COCREA}$ & 0.639 & 0.098 & 9.503 & $* * *$ \\
\hline ZL2 & 0.643 & & & \\
\hline $\mathrm{ZL} 3 \leftarrow \mathrm{BRLOYAL}$ & 0.832 & 0.112 & 12.185 & $* * *$ \\
\hline ZL4־BRLOYAL & 0.786 & 0.034 & 11.848 & $* * *$ \\
\hline ZL5־BRLOYAL & 0.588 & 0.104 & 9.497 & $* * *$ \\
\hline
\end{tabular}

Sobel Test results, test statistics was calculated as 3.802 while p value was calculated as 0.000 (http: //quantpsy.org/sobel). According to the mediation test results, it was determined that e-brand love and branding co-creation variables had a partial mediator role in the relationship between SMM activities and brand loyalty. The hypotheses H4 and H6 were accepted.

\section{CONCLUSION AND DISCUSSIONS}

In this study where it was aimed to examine the mediator role of e-brand love and brand co-creation in the effect of SMM activities on brand loyalty; the majority of the respondents consisted of single people, students and females who were in the 18-25 age range, received education at the undergraduate level and had an income level of $1000 \mathrm{TL}$ and below. However, the majority of respondents consisted of the individuals who used social media continuously and shared on social media actively. Instagram was the mostly used social media platform in terms of the followed brands. In the study, Zara was the most popular brand. The research model was analysed through the structural equation modelling. Following the analysis, all hypotheses established within the scope of the study were accepted. In line with the results obtained, the following suggestions were developed: Firstly, the three main dimensions of SMM activities were found to have a significant effect on e-brand love. These dimensions are entertainment, e-word of mouth and interaction. Secondly, SMM activities have an effect on branding co-creation similarly. The effect of e-brand love and branding co-creation on brand loyalty, which are third result of the study, is actually a proof of this situation. Finally, according to the mediator variable test results, it was determined that e-brand love and branding co-creation variables had a partial mediator role in the relationship between SMM activities and brand loyalty.

In this respect, the following suggestions have been developed. For the first research result, in line with the answers given by the respondents, it can be stated that they find the activities conducted by their "the most loved" brands through various social media tools enjoyable, are open to exchange of views and information sharing, and accordingly, think positively of the e-word of mouth. Due to effective information sharing and e-word of mouth, brands can become a "trend" in a short time and create a positive advertising process. At this point, we see that most of enterprises have made product launches specific to social media prior to general product launches in recent years and provided the opportunity of purchasing to social media users first. This situation can be used as a strategy that will establish a bond between the brand and consumers who have e-brand love. What is important at this point is to ensure that the e-consumer feels special. At this point, it is important to support the emotional intensity of consumers who have already begun to feel strong emotions towards the brand as a result of the activities that the 
brand conducted through social media. Furthermore, the consumer will be able to do more shares regarding the brand, contribute to the content formation and make the brand one of the "trends" and "mentioned" brands. While it is possible to mention this situation for both small and large enterprises, the use of the right social media tool is also important. Within the scope of the study, it was revealed that Instagram was an effective tool for love brands. The market segment to which enterprises address, the sharing of contents in line with their target audiences and the selection of the right social media tool will increase the effectiveness in this sense. On the other hand, selecting a single social media tool can be a wrong strategy. For this reason, by considering many factors such as consumer preferences, demographic characteristics, product category, brand characteristics, all social media tools can be utilized. This strategy can also be interpreted as the social media positioning strategy. The effect of social media continues to increase rapidly and new practices are emerging every day. It is important for enterprises to engage in these practices to stay updated and to carry out integrated marketing communication no matter which tool is preferred. At this point, conducting social media marketing according to generations may be another suggestion. With social media marketing practices conducted according to the generations, "privileged, differentiated and individual message presentation" can be realized according to target groups. Official accounts of brands can be effectively used in this sense and the support to be obtained from the "influencers" in the relevant field can be useful.

For the second research result, SMM activities have an effect on branding co-creation. In other words, consumers are more willing to contribute to the contents that they find entertaining, highly interactive and worth sharing. With the change of consumer habits, consumers expect brands to contact them. In other words, consumers want to have their own shares in a change to be made and an innovation to be realized. The point to take into consideration at this point is the emotional bond that consumers have established with brands. By participating in this process, consumers demonstrate that they emotionally look after their brands. Taking consumers into consideration in the process and receiving positive feedback in terms of their contributions to the brand will strengthen the existing emotional bond. It is important for enterprises not to lose this existing consumer group. Quick feedback, "if it weren't for you" messages and rewarding consumers both materially and spiritually will act as motivational factors in this sense. For this reason, suggestions regarding the planned changes such as "which one would you choose?" and "short questionnaire studies" may actually be the steps taken for including consumers in the process of branding co-creation, because consumers now demand a personalized experience. Otherwise, they can prefer another brand by abandoning the brands they use.

For the third research result; consumers no longer target the "traditional" but the "different" content where they have their "own contributions". The enterprises that are able to provide this to their consumers are the winning enterprises of today. Such activities make individuals "tag" other individuals in comment network and provide the opportunity to reach potential customers without any effort. These activities, which allow closer and emotional contact between the consumer-consumer and brand-consumer, can be used as an important step in gaining loyal customers. The value of the contents to which consumers have also contributions is very high, because now every consumer can have a channel, promote and interpret different areas and products. Accordingly, enterprises actually feel under pressure compared to the old market conditions, because the form of communication is shaped by consumers not by enterprises. Therefore, it is thought that the brands that can respond correctly to the demands of consumers under the market conditions where the rules are determined by consumers will be the love brands. The e-consumers who have brand love will be committed to their brands in social media.

For the final research result, while SMM activities affect e-brand love, it can be stated that e-brand love makes this relationship stronger on the path going to brand loyalty. Therefore, it will depend on social media strategies that love brands give more importance to SMM activities and make their consumers more loyal to their brands. Similarly, consumers, who are involved in the process of branding co-creation with SMM activities, strengthen brand loyalty as their effectiveness in this process increases. Accordingly, informing and including consumers in the process of branding co-creation through social media tools will increase the number of loyal consumers.

In the future studies to be conducted on the subject, the concept of e-brand love can be handled with different variables such as e-trust and e-commitment in the studies conducted regarding internet-mediated environments. Moreover, SMM activities can be evaluated comparatively in terms of various social media 
tools such as Instagram, YouTube and Facebook. Future studies can conduct researches on different brands and product groups. In addition, two or more sectors can be addressed and analysed. It can be examined influencers and bloggers, who have social media popularity and the power to influence a large group, have an effect on e-brand love and/or co-creation. A study regarding the development of a scale for e-brand love can be conducted in order to measure e-brand love more healthily through social media. 


\section{REFERENCES}

Agichtein, E., Castillo, C., Donato, D. Gionis, A. and Mishne, G. (2008), Finding High Quality Content in Social Media". Proceedings of the 2008 International Conference on Web Search and Data Mining, 1112 February 2008, (pp. 183-194), California, USA.

Algharabat, R. S. (2017), Linking Social Media Marketing Activities with Brand Love: The Mediating Role of Self-Expressive Brands. Kybernetes, 46(10), pp.1801-1819.

Baena, V. (2016), Online and Mobile Marketing Strategies as Drivers of Brand Love in Sports Teams: Findings from Real Madrid. International Journal of Sports Marketing and Sponsorship, 17(3), pp.202218.

Balakrishnan, B. K., Dahnil, M. I. and Yi, W. J. (2014), The Impact of Social Media Marketing Medium Toward Purchase Intention and Brand Loyalty among Generation Y. Procedia-Social and Behavioral Sciences, 148, pp.177-185.

Batra, R., Ahuvia, A. and Bagozzi, R.P. (2012), Brand Love, Journal of Marketing, 76(2), pp.1-16.

Carroll, B. and Ahuvia, A.C. (2006), Some Antecedents and Outcomes of Brand Love. Marketing Letters, 17(2), pp.79-89.

Chung, C. and Austria, K. (2010), Social Media Gratification and Attitude Toward Social Media Marketing Messages: A Study of the Effect of Social Media Marketing Messages on Online Shopping Value. Proceedings of the Northeast Business \& Economics Association, pp.581-586.

Cifci, S. and Sözen, D. (2017), Tüketicilerin Sosyal Medya Pazarlama Aktivitelerine Katılımlarının Etkileyicileri ve Sonuçları. Ege Akademik Bakış Dergisi, 17(4), pp.505-515.

Cvijikj, I. P. and Michahelles, F. (2013), Online Engagement Factors on Facebook Brand Pages. Social Network Analysis and Mining, 3(4), pp.843-861.

Ehlen, C., van der Klink, M., Stoffers, J. and Boshuizen, H. (2017), The Co-Creation-Wheel: A FourDimensional Model of Collaborative Interorganisational Innovation. European Journal of Training and Development, 41(7), pp.628-646.

Erdoğmuş, İ. E. and Çicek, M. (2012), The Impact of Social Media Marketing on Brand Loyalty. Procedia-Social and Behavioral Sciences, 58, pp.1353-1360.

Felix, R., Rauschnabel, P. A. and Hinsch, C. (2017), Elements of Strategic Social Media Marketing: A Holistic Framework. Journal of Business Research, 70, pp.118-126.

France, C., Merrilees, B. and Miller, D. (2015), Customer Brand Co-Creation: A Conceptual Model. Marketing Intelligence \& Planning, 33(6), pp.848-864.

Gamboa, A. M. and Gonçalves, H. M. (2014), Customer Loyalty Through Social Networks: Lessons from Zara on Facebook. Business Horizons, 57(6), pp.709-717.

Godey, B., Manthiou, A., Pederzoli, D., Rokka, J., Aiello, G., Donvito, R. and Singh, R. (2016), Social Media Marketing Efforts of Luxury Brands: Influence on Brand Equity and Consumer Behavior. Journal of Business Research, 69(12), pp.5833-5841.

Gommans, M., Krishman, K. S. and Scheffold, K. B. (2001), From Brand Loyalty to E-Loyalty: A Conceptual Framework. Journal of Economic \& Social Research, 3(1), pp.43-58.

Gounaris, S. and Stathakopoulos, V. (2004), Antecedents and Consequences of Brand Loyalty: An Empirical Study. Journal of Brand Management, 11(4), pp.283-306.

Hair, J.F.Jr., Rolph E. A., Ronald L.T. and William C. B. (1998), Multivariate Data Analysis. PrenticeHall. Inc, New Jersey.

Hajli, N., Shanmugam, M., Papagiannidis, S., Zahay, D. and Richard, M. O. (2017), Branding CoCreation with Members of Online Brand Communities. Journal of Business Research, 70, pp.136-144. 
Hennig-Thurau, T., Gwinner, K. P., Walsh, G. and Gremler, D. D. (2004), Electronic Word-of-Mouth Via Consumer-Opinion Platforms: What Motivates Consumers to Articulate Themselves on The Internet? Journal of Interactive Marketing, 18(1), pp.38-52.

Hoyer, W. D., Chandy, R., Dorotic, M., Krafft, M. and Singh, S. S. (2010), Consumer Co-Creation in New Product Development. Journal of Service Research, 13(3), pp.283-296.

Hsieh, S. H. and Chang, A. (2016), The Psychological Mechanism of Brand Co-Creation Engagement. Journal of Interactive Marketing, 33, pp.13-26.

Ismail, A. R. (2017), The Influence of Perceived Social Media Marketing Activities on Brand Loyalty: The Mediation Effect of Brand and Value Consciousness. Asia Pacific Journal of Marketing and Logistics, 29(1), pp.129-144.

Kamboj, S., Sarmah, B., Gupta, S. and Dwivedi, Y. (2018), Examining Branding Co-Creation in Brand Communities on Social Media: Applying the Paradigm of Stimulus-Organism- Response. International Journal of Information Management, 39, pp.169-185.

Karjaluoto, H., Munnukka, J. and Kiuru, K. (2016), Brand Love and Positive Word of Mouth: The Moderating Effects of Experience and Price. Journal of Product \& Brand Management, 25(6), pp.527537.

Kaufmann, H. R., Loureiro, S. M. C. and Manarioti, A. (2016), Exploring Behavioural Branding, Brand Love and Brand Co-Creation. Journal of Product \& Brand Management, 25(6), pp.516-526.

Kim, A. J. and Ko, E. (2012), Do Social Media Marketing Activities Enhance Customer Equity? An Empirical Study of Luxury Fashion Brand. Journal of Business Research, 65(10), pp.1480-1486.

Kim, E., Sung, Y. and Kang, H. (2014), Brand Followers' Retweeting Behavior on Twitter: How Brand Relationships Influence Brand Electronic Word-Of-Mouth. Computers in Human Behavior, 37, pp.18-25.

Laroche, M., Habibi, M. R. and Richard, M. O. (2013), To Be or Not to Be in Social Media: How Brand Loyalty Is Affected by Social Media? International Journal of Information Management, 33(1), pp.76-82.

Machado, J. C., Vacas-de-Carvalho, L., Azar, S. L., André, A. R. and dos Santos, B. P. (2019), Brand Gender and Consumer-Based Brand Equity on Facebook: The Mediating Role of Consumer-Brand Engagement and Brand Love. Journal of Business Research, 96, pp.376-385.

Merrilees, B. and Fry, M. L. (2003), E-Trust: The Influence of Perceived Interactivity on E-Retailing Users. Marketing Intelligence \& Planning, 21(2), pp.123-128.

Muntinga, D. G., Moorman, M. and Smit, E. G. (2011), Introducing Cobras: Exploring Motivations for Brand-Related Social Media Use. International Journal of Advertising, 30(1), pp.13-46.

Oliver, R. L. (1999), Whence Consumer Loyalty?. The Journal of Marketing, 64(3), pp.33-44.

Piller, F. T., Vossen, A. and Ihl, C. (2012), From Social Media to Social Product Development: The Impact of Social Media on Co-Creation of Innovation. Die Unternehmung, 65(1), pp.1-22.

Quantpsy.org (2019). http://quantpsy.org/sobel/sobel.htm. Date Accessed: 01.09.2019.

Ruiz-Mafe, C., Martí-Parreño, J. and Sanz-Blas, S. (2014), Key Drivers of Consumer Loyalty to Facebook Fan Pages. Online Information Review, 38(3), pp.362-380.

Saravanakumar, M. and SuganthaLakshmi, T. (2012), Social Media Marketing. Life Science Journal, 9(4), pp.4444-4451.

Seo, E. J. and Park, J. W. (2018), A Study on The Effects of Social Media Marketing Activities on Brand Equity and Customer Response in The Airline Industry. Journal of Air Transport Management, 66, pp.3641.

Tekbiyık, K. (2017), Impact of Brand Love on Focal Online and Offline Consumer Behavior Outcomes (Master Thesis). İstanbul: Marmara Üniversitesi Sosyal Bilimler Enstitüsü. 
Vernuccio, M., Pagani, M., Barbarossa, C. and Pastore, A. (2015), Antecedents of Brand Love in Online Network-Based Communities. A Social Identity Perspective. Journal of Product \& Brand Management, 24(7), pp.706-719.

Wallace, E., Buil, I. and de Chernatony, L. (2014), Consumer Engagement with Self-Expressive Brands: Brand Love and WOM Outcomes. Journal of Product \& Brand Management, 23(1), pp.33-42.

Wang, Y. and Hajli, M. (2014), Co-Creation in Branding Through Social Commerce: The Role of Social Support, Relationship Quality and Privacy Concerns. In Proceedings of Twentieth Americas Conference on Information Systems, (pp. 1-16), Savannah, Georgia.

Yadav, M. and Rahman, Z. (2017), Measuring Consumer Perception of Social Media Marketing Activities in E-Commerce Industry: Scale Development \& Validation. Telematics and Informatics, 34(7), pp.1294-1307. 